\title{
Priority of Rhodococcus lentifragmentus (Kruse 1896; Tsukamura et al. 1975) Tsukamura 1978 comb. nov. over Rhodococcus ruber (Kruse 1896) Goodfellow and Alderson 1980
}

\author{
Request for an Opinion \\ MICHIO TSUKAMURA \\ The National Chubu Hospital, Obu, Aichi, Japan 474
}

\begin{abstract}
Rhodococcus lentifragmentus (Kruse 1896; Tsukamura et al. 1975) Tsukamura 1978 comb. nov. has priority over Rhodococcus ruber (Kruse 1896) Goodfellow and Alderson 1980. On the Approved Lists 1980, the year of valid publication of the name Rhodococcus ruber appears as 1979. This should be 1980, as this name was not effectively published before the Approved Lists 1980. I propose that the Judical Commission of the International Committee on Systematic Bacteriology revise the name Rhodococcus lentifragmentus by recognizing its priority over Rhodococcus ruber.
\end{abstract}

The name Rhodococcus lentifragmentus (Kruse 1896; Tsukamura et al. 1975) Tsukamura 1978 comb. nov. has priority over the name Rhodococcus ruber (Kruse 1896) Goodfellow and Alderson 1980, which appears on the Approved Lists 1980 (6). Rhodococcus lentifragmentus should replace Rhodococcus ruber. The reasons for this are given below.

In 1969, Tsukamura (7) placed the taxa previously named "Nocardia rubra," "Nocardia erythropolis," "Nocardia globerula," "Nocardia polychromogenes," "Nocardia minima," and "Nocardia lutea" into one species, "Nocardia rubra." In 1975, Tsukamura et al. (12) transferred some strains of "Nocardia rubra" (all strains except the strains named "Nocardia erythropolis," "Nocardia globerula," and "Nocardia polychromogenes") into the genus "Gordona" (8) and named these strains "Gordona lentifragmenta" Tsukamura nom. nov. This name was chosen to avoid confusion with "Gordona rubra" (8), which was described in 1971 as a species of the genus "Gordona" and later became a synonym of "Gordona rubropertincta" (Hefferan 1904) Tsukamura (9) or Rhodococcus rubropertinctus (Hefferan 1904) Tsukamura 1974/1978 $(10,11)$. When, in 1978 , Tsukamura (11) proposed to change the generic name from "Gordona" to Rhodococcus, this taxon was named Rhodococcus lentifragmentus Tsukamura 1978. The articles of Tsukamura et al. (12) of 1975 and Tsukamura (11) of 1978 were published effectively in the International Journal of Systematic Bacteriology (IJSB). Therefore, the name Rhodococcus lentifragmentus (Kruse 1896; Tsukamura et al. 1975) Tsukamura comb. nov. 1978 was validly published in 1978.

Goodfellow and Alderson (2) also transferred "Nocardia rubra" to the genus Rhodococcus in 1977 as Rhodococcus rubrus (Kruse 1891) Tsukamura 1971 comb. nov. (correct name, Rhodococcus ruber), citing the reference of Tsukamura et al. (12). However, this article (2) was not published in the IJSB. According to the International Code of Nomenclature of Bacteria (4), when a new name or combination is published outside the IJSB, the pertinent reference to the name or combination must be cited in the IJSB, and the date of valid publication of the new name or combination is the date of publication in the IJSB (5). Consequently, the name Rhodococcus ruber was not valid until the Approved Lists (6) erroneously included this name in 1980. The Approved Lists (6) cite the date of publication of Rhodococcus ruber as 1979. This is erroneous, as, in 1979, two names described by Goodfellow and Alderson (2), Rhodococcus rhodnii and Rhodococcus erythropolis, were announced in the IJSB (3), but the name Rhodococcus ruber was not announced. Therefore, the date of publication of this name is not 1979 but 1980 , when the Approved Lists appeared.

Furthermore, the citation of the name "Rhodococcus rubrus, (Kruse 1896) Tsukamura 1971" by Goodfellow and Alderson (2) is not correct. There is no publication by Tsukamura in this year concerned with this taxon. Goodfellow and Alderson probably confused the name with the name of another taxon "Gordona rubra" (8), which is now a synonym of Rhodococcus rubropertinctus (Hefferan 1904) Tsukamura comb. nov. $(10,11)$. To avoid future confusion, the name Rhodococcus lentifragmentus is preferable. In addition, the American Type Culture Collection catalog (1) lists erroneously the type strain of the species Rhodococcus lentifragmentus as that of the species "Gordona rubra."

The description of the species Rhodococcus lentifragmentus is that prepared in 1975 by Tsukamura et al. (12) for "Gordona lentifragmenta." The type strain is strain ATCC 27863 (- National Chubu Hospital strain NCH 23022 - N.M. McClung strain M-1).

\section{LITERATURE CITED}

1. American Type Culture Collection. 1980. Catalogue of strains I. American Type Culture Collection, Rockville, Md.

2. Goodfellow, M., and G. Alderson. 1977. The actinomycetegenus Rhodococcus: a home for the 'rhodochrous' complex. J. Gen. Microbiol. 100:99-122.

3. International Journal of Systematic Bacteriology. 1979. Validation of the publication of new names and new combinations previously effectively published outside the IJSB. List no. 2. Int. J. Syst. Bacteriol. 29:79-80.

4. Lapage, S. P., P. H. A. Sneath, E. F. Lessel, V. B. D. Skerman, H. P. R. Seeliger, and W. A. Clark (ed.). 1975. International code of nomenclature of bacteria. 1975 Revision. American Society for Microbiology, Washington, D.C.

5. Lessel, E. F. 1977. Concerning the valid publication of new names and combinations effectively published on or after 1 January 1976 in publications other than the IJSB. Int. J. Syst. Bacteriol. 27(3):iv.

6. Skerman, V. B. D., V. McGowan, and P. H. A. Sneath (ed.). 1980. Approved lists of bacterial names. Int. J. Syst. Bacteriol. 
30:225-420.

7. Tsukamura, M. 1969. Numerical taxonomy of the genus Nocardia. J. Gen. Microbiol. 56:265-287.

8. Tsukamura, M. 1971. Proposal of a new genus, Gordona, for slightly acid-fast organisms occurring in sputa of patients with pulmonary disease and in soil. J. Gen. Microbiol. 68:15-26.

9. Tsukamura, M. 1973. A taxonomic study of strains received as "Mycobacterium" rhodochrous. Description of Gordona rhodochroa (Zopf; Overbeck; Gordon et Mihm) Tsukamura comb.nov. Jpn. J. Microbiol. 17:189-197.
10. Tsukamura, M. 1974. A further numerical taxonomic study of the rhodochrous group. Jpn. J. Microbiol. 18:37-44.

11. Tsukamura, M. 1978. Numerical classification of Rhodococcus (formerly Gordona) organisms recently isolated from sputa of patients: description of Rhodococcus sputi Tsukamura sp. nov. Int. J. Syst. Bacteriol. 28:169-181.

12. Tsukamura, M., S. Mizuno, and H. Murata. 1975. Numerical taxonomy study of the taxonomic position of Nocardia rubra reclassified as Gordona lentifragmenta Tsukamura nom. nov. Int. J. Syst. Bacteriol. 25:377-382. 